senior lecturer in mechanical engineering in the Faculty of Science at the University of Manchester. His researches during this period in the Faculty of Science were extended, but especially he has made considerable contributions to knowledge about the fundamental mechanics of metal extrusion and forging. Mr. Johnson is editor and founder of the International Journal of the Mechanical Sciences.

\section{Botany at Newcastle on Tyne : \\ Prof. Meirion Thomas, F.R.S.}

WHEN he retires from the chair of botany at King's College, Newcastle on Tyne, at the end of the present session, Prof. Meirion Thomas will have completed thirty-six years service in the Botanical Department of that institution, first as lecturer during 1924-43, then as reader until 1946 when he was appointed to the chair in succession to Prof. J. W. Heslop Harrison. After serving in the army throughout the First World War, first in the South Wales Borderers, but for most of the time with the Royal Engineers, Prof. Thomas entered Trinity Hall, Cambridge, where he remained until his appointment to the lecturership in Newcastle. At Cambridge, he combined the study of biochemistry and botany with achievement in the field of sport, obtaining his 'blue' in association football. Prof. Thomas is distinguished for his long series of researches in plant metabolism, particularly in regard to the respiratory and allied processes in apple fruit and succulent plants. Many of his papers have appeared in the New Phytologist. He was president of Section K (Botany) of the British Association at its Belfast Meeting in 1952 where his presidential address was a masterly review of our knowledge of such metabolic processes in higher plants. Prof. Thomas is also the author of a well-known text-book on plant physiology, the success of which may be judged from the fact that it is now in its fourth edition. His friends will wish him a long and happy retirement. $\mathrm{He}$ is to be succeeded by Prof. J. H. Burnett, professor of botany in the University of St. Andrews (see Nature, 176, $1002 ; 1955)$.

\section{Bacteriology at St. Mary's Hospital :}

Prof. R. E. O. Williams

DR. R. E. O. Williams, who has been appointed to une chair of bacteriology at St. Mary's Hospital, has long maintained an interest in both the scientific and the clinical aspects of bacteriology. Dr. Williams was educated at Sherborne School and the University of London. He obtained a B.Sc. at University College in 1937 and read medicine at University College Hospital, qualifying in 1940. He entered the Emergency Medical Service in 1941 and transferred to the Medical Research Council Wound Infection Unit in 1942. In 1946 he joined the Public Health Laboratory Service and was appointed director of the Streptococcal and Staphylococcal Reference Laboratories and of the Air Hygiene Unit in 1949. Dr. Williams has made a special study of hospital cross-infection, and the laboratories in which he has worked and has later directed have made notable contributions to this field. His name is associated particularly with important research into air hygiene and the typing of streptococci and staphylococci. In the latter context the energetic development of phage typing in the epidemiology of staphylococcal infections has been of prime importance and owes a great deal to him and his group. Dr. Williams has published numerous papers on all the facets of bacteriology in which he is interested. He has travelled extensively and is well known to scientific colleagues in manycountries.

\section{Royal Society Tercentenary Exhibition}

As one of the functions of the Royal Society tercentenary celebrations this year, a conversazione is to be held at Burlington House on the evening of July 23. There will be on this occasion an exhibition in the Diploma Galleries of the Royal Academy of Arts, illustrating British scientific achievements during recent years. The exhibition will differ somewhat from that usually arranged for a Royal Society soirée. There will be fifteen sections, each devoted to some field of science in which British contributions have been of outstanding importance, and in most cases several research centres will be represented in each section. The fields which have been selected are: calculating machines; physics of the Earth, ocean and atmosphere; exploration by radio; fundamental particles; solvent extraction of plutonium ; refined chemical separation; metals ; molecular structure of biological systems; abnormal hæmoglobins and human chromosomes; natural selection; microbial genetics; antibiotics ; vitamins : electrophysiology; physiological and biochemical aspects of plant growth. The exhibition will remain open from $10.30 \mathrm{a} . \mathrm{m}$. to $6 \mathrm{p} . \mathrm{m}$. from Monday, July 25. until Friday, July 29. On Monday, Tuesday and Wednesday, admission will be by ticket only. Schools, colleges, scientific societies and professional institu. tions are being informed of the exhibition and tickets will be issued to them. On July 28 and 29 the exhibition will be open to the public.

\section{U.S. Expenditure on Academic Research and Development}

A PRELIMINaRy report on research and development in colleges and universities in the fiscal year 1958 issued by the National Science Foundation shows that during 1954-58 expenditure on research and development in the natural and social sciences at colleges and universities in the United States increased from $409 \cdot 7$ million dollars to $735 \cdot 8$ million dollars, in which period Federal expenditure for research and development in colleges and universities proper increased from $140 \cdot 7$ million to 217.9 million dollars. In 1958 expenditure on research and development in colleges and universities proper amounted to 327.5 million dollars; agriculture experiment stations, including schools of agriculture, to $119 \cdot 2$ million dollars; and in Federal contract research centres, to $289 \cdot 1$ million dollars. At universities and colleges proper 74 per cent of this expenditure was on fundamental research, compared with 35 per cent at agricultural experiment stations and 24 per cent at Federal contract research centres. Of the total 735.8 million dollars, 186.4 million dollars was expended in engineering sciences $(26 \cdot 3$ per cent on fundamental research); $262 \cdot 3$ million dollars on physical sciences $(49.5$ per cent); 251.5 million dollars on biological sciences ( 61.7 per cent); and 35.6 million dollars on social sciences $(56 \cdot 9$ per cent $)$. Of the 327.5 million dollars expended at colleges and universities proper, 67 per cent came from the Federal Government, 12 per cent from the Institution's own funds, 11 per cent from foundations. 8 per cent from industry and 2 per cent from other sources. Total indirect, or overhead, costs of conducting current research are estimated at 28 per cent of direct costs. 